Liana Chernobay, Ph.D., Professor of Management and International Entrepreneurship Department, Lviv Polytechnic National University (Lviv, Ukraine)

Sviatoslav Malibroda, Ph.D. graduate of "International economic relationships", assistant at Management and International Entrepreneurship Department Lviv Polytechnic National University (Lviv, Ukraine)

\title{
THE METHOD FOR ESTIMATING THE IMPACT OF MIGRANTS' REMITTANCES ON THE FINANCIAL AND ECONOMIC DEVELOPMENT OF A COUNTRY
}

\begin{abstract}
The study presents a method for estimating the financial and economic impact of personal remittances on economic development migrants' origin country. The relevance of the study refers to the high dependence of such countries on migrants' remittances. The developed method includes estimating the share of GDP, internal consumption, savings, imports and net cash flow in the balance of payments caused by remittances impact. Obtained estimation provides evidence of significant positive impact of remittances on receiving countries as their GDP, depending on the country, may decrease even for 5\% when remittances drop for $10 \%$.
\end{abstract}

Keywords: migration, remittances, estimation, method, GDP, balance of payments

\section{Introduction}

International migration or, a bit descriptive, movement of people across the borders, is, from another side, a movement of people from one economy to another. These movements consequently have their effects on both domestic and host economy. Some effects are common for both economies but are a kind reflected. When the host economy benefits from increasing consumption, the original economy experience the decreasing in consumption. When the original economy benefits from receiving remittances, the host economy experiences the money outflow.

The estimation of some of these effects, however, involves only one common indicator, the number of migrants, and other indicators are individual for each economy. If one estimates the consumption effect on the host economy, one might, for example, use the average consumption per person in the host economy multiplied by the number of migrants hosted. If one estimates the consumption effect for the country of the country of origin, one 
might, for example, use the average consumption per person in this economy multiplied by the number of migrants.

The estimation of other effects also involves the number of migrants but depends only on indicators of one country. The amount of remittances sent and then received depends on the number of migrants and the factors of the host economy, e.g. salary and average consumption.

Moreover, some direct effects of international migration like remittances generate consequent effects for the country of the country of origin. In the scope of the current study, we focus specifically on remittances and its effects on the country of origin.

When remittances are received by households, they are distributed for consumption and savings. The consumption in its turn is distributed for internal consumption and imports. Then the internal consumption from the other side becomes one's income, which again is spent on savings, internal consumption and imports. And then again, it creates a multiplier effect.

The main variable for such calculation is obviously the amount of received remittances. Assuming that the amount of remittances depends on the number of migrants and economic conditions in the host economy, it is logical to assume that the amount of savings, internal consumption and imports along with its multiplied amounts caused by remittances effects depend on the number of migrants and economic conditions in the host economy.

From this standpoint, the aim of the study is to provide a method of estimating the amounts of savings, internal consumption and imports, and its joint impact on the GDP and net money flows caused by impact of remittances.

The relevance of the study refers to the high remittances to GDP ratio in many countries and escalation of the global pandemic and the further economic crises which strongly affect the migrants' mobility (consequently their number) and deteriorate the economic conditions in the host economies.

Current study use findings of our previous research (Malibroda, et al., 2020) focusing on the remittances impact on economic and financial development.

\section{Literature overview}

Current studies of the remittances effects on origin economies are divided into three wings considering their conclusions about remittances impact on economy: positive, no impact, and negative; and two wings considering the approaches scientists primarily use: statistical analysis or specifying existing economic theories, mainly Keynesian. Referring to 
such "classification", this study provides the conclusion of positive impact of remittances specifying Keynesian economics.

When scientists who specify economic theories argue that remittances have a positive impact, those who use statistical analysis provide controversial evidences. Cazachevici, Havrane, Horvath (2020) analysed 95 studies and concluded that "approximately $40 \%$ of the studies report a positive effect, $40 \%$ report no effect, and $20 \%$ report a negative effect".

Studies which report no impact or negative impact are represented by studies that, widely speaking, apply statistical methods to determine whether it is a correlation between remittances and GDP or not. Many of such studies have not found statistically significant evidence that remittances influence the GDP growth. Some conclude "that, at best, workers' remittances have no impact on economic growth" (Gapen, et al., 2019). Chami, Fullenkamp and Jahjas (2003) investigated that remittances have a negative impact on the economy. The results of Cazachevici, Havrane, Horvath (2020) study show that mean remittances effect is positive but economically small.

Such conclusions might be accurate in terms of applying statistical methods, but do not fit existing economic theories. Provided evidence might occur as a result the lack of data or incomplete models, however, not because of absence of impact or existing a negative impact. If one tends to accept these conclusions, the further questions have to be answered: 'Will the economy grow or remain the same if all received remittances are extracted at one time? What if remittances equal $20 \%$ of GDP? Will it help? What about aggregate demand and employment?'

Other studies that use the same methods found the positive impact of remittances on economy. Some of these studies also provide a strong fundamental explanation of how remittances influence the economy. Further literature overview contains studies based on both statistical methods and economic theories analysis.

Oladipo (2020) in the research found that $1 \%$ increase in remittances leads to an increase for $0.0238 \%$ of GDP in Nigeria. The author in his literature overview also provided evidence of positive impact from panel studies by Imai, et al. (2014), used GMM-IV model, Marwan et al. (2013), used the Johansen cointegration technique, Salahuddin (2013), used OLS methods, and others. Feeny, et al. (2014) found the positive impact in small island countries, concluding also that the correlation might depend on the country's size. Nsiah, Christian et al. (2013) provided an evidence of positive impact for American-Caribbean countries. Shahbuz, Nurul Shahnaz Ahmad (2013) found that remittances caused the 
economic growth in Pakistan. Pradhan, Upadhyay and Upadhyaya (2008) using a panel data from 39 developing countries also found a positive impact on growth.

Pirvu, Badarcea, Manta and Florea (2018) discovered the positive effect on the balance of payments and concluded that remittances might replace foreign financial assistance. Also, the authors note that remittances could positively influence investments, especially by creating small enterprises. However, the authors admit that the effect of increasing aggregate demand might increase inflation and widen the trade deficit. Nevertheless, origin economies typically are far from full employment and need much more inflows to reach the point when inflation starts to rise.

Mundaca's (2009) study shows that the development of financial sector leads to better use of remittances and therefore boosts its positive impact on growth. Another important conclusion is revealed by Mundaca (2009) from studies of Lucas (1987), Rozelle et al. (1999), and Woodruff and Zenteno (2007). The author assumes that "remittances allow households at the middle-to-bottom end of the wealth distribution, who are most likely to be credit constrained, to accumulate productive assets and to have access to self-employment and entrepreneurship". Woodruff and Zenteno (2007) found that a third of capital invested in micro-enterprises in Mexico come from migrants in the US. Such a conclusion coincides with previously mentioned impact on investments through creating small enterprises. Simply speaking, when a person has enough money for food, housing etc. he or she might start to invest money.

The research by Stahl and Arnold (1986) contains data on the distribution of remittances by households in Bangladesh, India, Pakistan, Philippines, South Korea, Sri Lanka and the Middle East of Thailand. It was found that expenditure patterns of households were similar in these countries. The significant share of remittances was spent on the purchase or constructing of a house. Authors also admit that the pessimistic view of remittances' potential to stimulate the development reflects misguided theoretical thinking. Instead, remittances cause the multiplier effect, which increases the aggregate demand to a higher amount than received remittances. A part of additional income will be lost to imports, but another part will stimulate the local industries.

Catrinescu, et al. (2009) find that remittances influence positively on economic growth and conclude that developed institutions and policies enhance such influence in a long-term period. Singh, et al. (2010), using a regression analysis for a data set from 36 countries, found a negative regression but admitted that well-functioning institutions can exert the positive impact of remittances on growth. Peprah, Kwesi Ofori, Asomani Camarero (2019) estimated 
the common and individual effects of remittances and financial sector on Ghana's economy and revealed that its common impact is higher than individual and then concluded that for better growth enhancing the better policies on remittances and financial sector have to be developed at the same time.

Considering the influence of remittance on the balance of payments, some scientists point out that remittance might cause the "Dutch disease" or might become a kind of "natural resource curse". However, Saad-Filho and Weeks (2013) note that even if such influence occurs, it is a result of political decisions, not the structural problems. Hassan and Holmes (2016) admit that remittances have a positive impact on the current account balance and facilitate its sustainability. Controversial to previous authors' conclusion was made by Farzanegan and Hassan (2019). In research of Middle Eastern and North African countries, authors concluded that remittances effected in increasing of trade deficit by increasing import expenditures. Tung (2018) provides the same conclusions due to OLS, 2-SLS and PGMM regression analysis of 17 countries in the Asia-Pacific region. From this standpoint, remittances indeed exert imports, however, the amount of import caused by remittances can exceed the amount of received remittances only at specific circumstances, which are explained in the further section.

\section{Theoretical findings}

Adhering to Keynesian economics we make an attempt to provide a theoretical explanation of how the remittances affect the receiving economy, its consumption, saving, imports, GDP and trade balance.

Provided theoretical findings are based on the key elements of The General Theory of Employment, Interest and Money (Keynes, 1936) adapting them particularly for estimating the remittances' impact on receiving countries. Further assumptions, its graphic illustrations and mathematical interpretation are developed by authors of the current study using Keynes' assumptions about consumption, aggregate demand, savings, investments, marginal propensities and, finally, about multiplier.

The remittances are actually the income of households receiving them. This income then is spent on consumption and savings. Consumption in its turn is divided into internal consumption and imports (see Figure 1). 


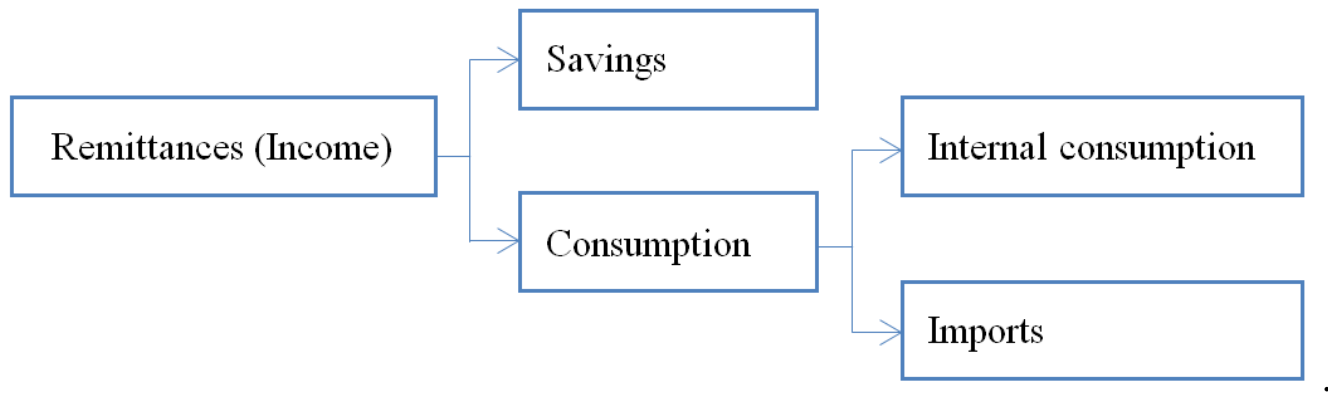

\section{Figure 1. An initial distribution of remittances*}

* developed by authors adapting The General Theory of Employment, Interest and Money (Keynes, 1936)

Using Keynesian's equation $\mathrm{I}=\mathrm{S}$, we might assume that all saving can be converted into investments. However, a part of those who make savings keep it in cash and a part brings it to financial institutions. The extent at which savings are converted into investments depends on the level of development of financial institutions as it was mentioned in the previous section.

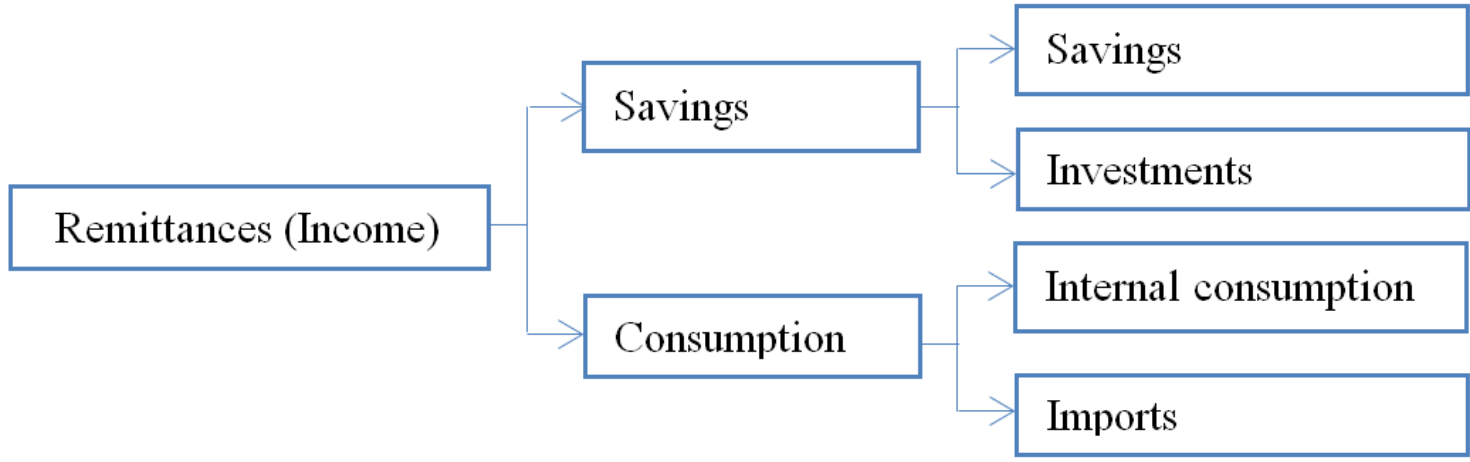

Figure 2. An initial distribution of remittances and savings*

* developed by authors adapting The General Theory of Employment, Interest and Money (Keynes, 1936)

What we can assume about savings is that in some period of time some part of savings will be spent on consumption or investments. Obtaining numbers for conducting its accurate calculation requires specific research of households' behaviour.

Finally, if we consider that internal consumption, from other side, is an income of domestic households, we obtain a model of remittances impact on receiving economy (see figure 3$)$. 


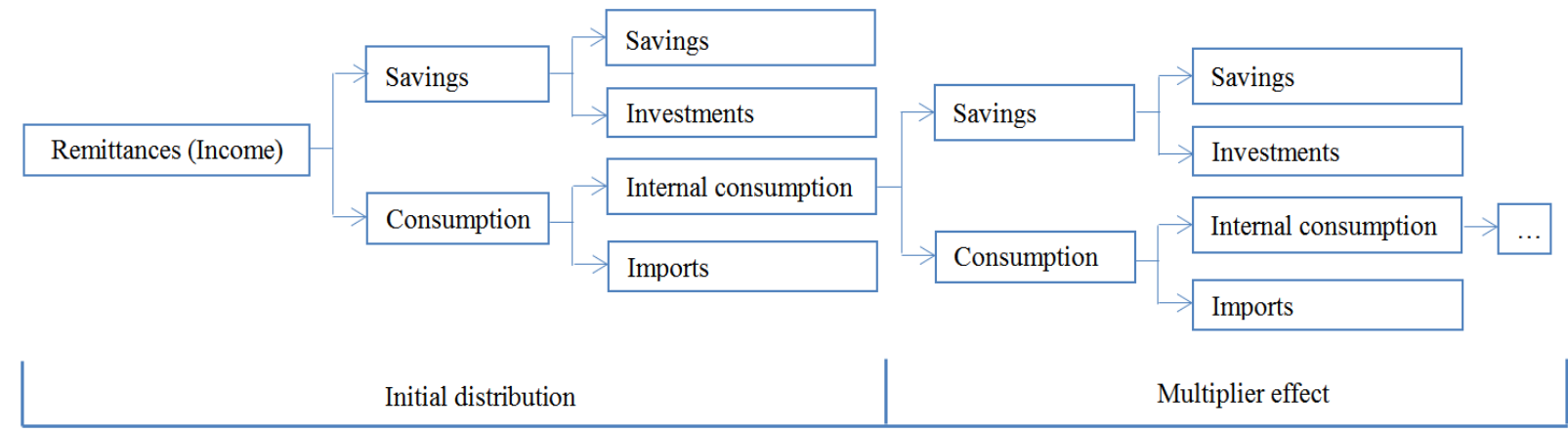

Figure 3. A model of remittances impact on receiving economy*

* developed by authors adapting The General Theory of Employment, Interest and Money (Keynes, 1936)

We developed further equations (1-3) for estimating the remittances effects on amounts of internal consumption $\left(\mathrm{C}_{\mathrm{I}}\right)$, Imports (Imp) and Savings $(\mathrm{S})$ caused by remittances (R) along with its multiplied amounts:

$$
\begin{gathered}
C_{I}=R * \frac{M P C *(1-M P M)}{(1-M P C *(1-M P M))}=R * M_{C_{I}}^{R} \\
I m p=R * \frac{M P C * M P M}{(1-M P C *(1-M P M))}=R * M_{I m p}^{R} \\
S=R * \frac{(1-M P C)}{(1-M P C *(1-M P M))}=R * M_{S}^{R}
\end{gathered}
$$

The $M_{C_{I}}^{R}, M_{I m p}^{R}$ and $M_{S}^{R}$ in equations 1-3 are the remittances' multiplier of internal consumption, imports and savings. MPC is the marginal propensity to consume; MPM is the marginal propensity to import. The calculated amount of savings contains the amounts of savings "in cash" and investments, as it is shown on figure 3.

Assuming that all savings will be spent on consumption or investments within one year, the share of GDP caused by remittances equals:

$$
\begin{gathered}
G D P_{R}=\frac{C_{I}+S}{G D P} * 100 \% \\
\text { or } \\
G D P_{R}=\left(\frac{R}{G P D} * 100 \%\right) *\left(\frac{1-M P C * M P M}{1-M P C *(1-M P M)}\right)=\left(\frac{R}{G P D} * 100 \%\right) * M_{G D P}^{R}
\end{gathered}
$$

In equation 5 the share of GDP caused by remittances is calculated as remittances-to-GDP ratio multiplied by remittances multiplier of GDP.

Using multipliers is quite convenient as it provides a clear answer of how each e.g. dollar of remittances received influences the receiving economy. For example, the remittances' multiplier of GDP 1.5 means that each dollar of remittances received causes the 1.5 dollar increase in GDP. The remittances' multiplier of import 0.7 means that each dollar of remittances received causes the 0.7 dollar increase in import. 
The remittances impact on the balance of payments occurs when remittances received cause the money inflows and imports conditioned by remittances cause the money outflow. The remittances impact on the country's BoP can be calculated as the net amount from money inflows and outflows:

$$
B o P_{R}=R-I m p
$$

If $\mathrm{BoP}_{\mathrm{R}}>0$ then the remittances influence positively and vice versa. Other words, if the $\mathrm{BoP}_{R}>0$ then the remittances cause the net inflow. If the $\mathrm{BoP}_{R}<0$ then the remittances cause the net outflows. The amount of net inflows or outflows equal $\mathrm{BoP}_{\mathrm{R}}$.

One can fairly admit that this model does not include the government. Such simplification is made under the assumption that taxes received by the government during the distribution of income from internal consumption will be spent and accounted in total consumption and investments. Obviously, government and households distribute their income/taxes in different ways and consideration of this will improve the calculation accuracy. However, it significantly complicates the calculation, so we use equations above due to the model presented on figure 3 .

Adding a government, we obtain an extended model of remittances impact on receiving economy (see figure 4 ).

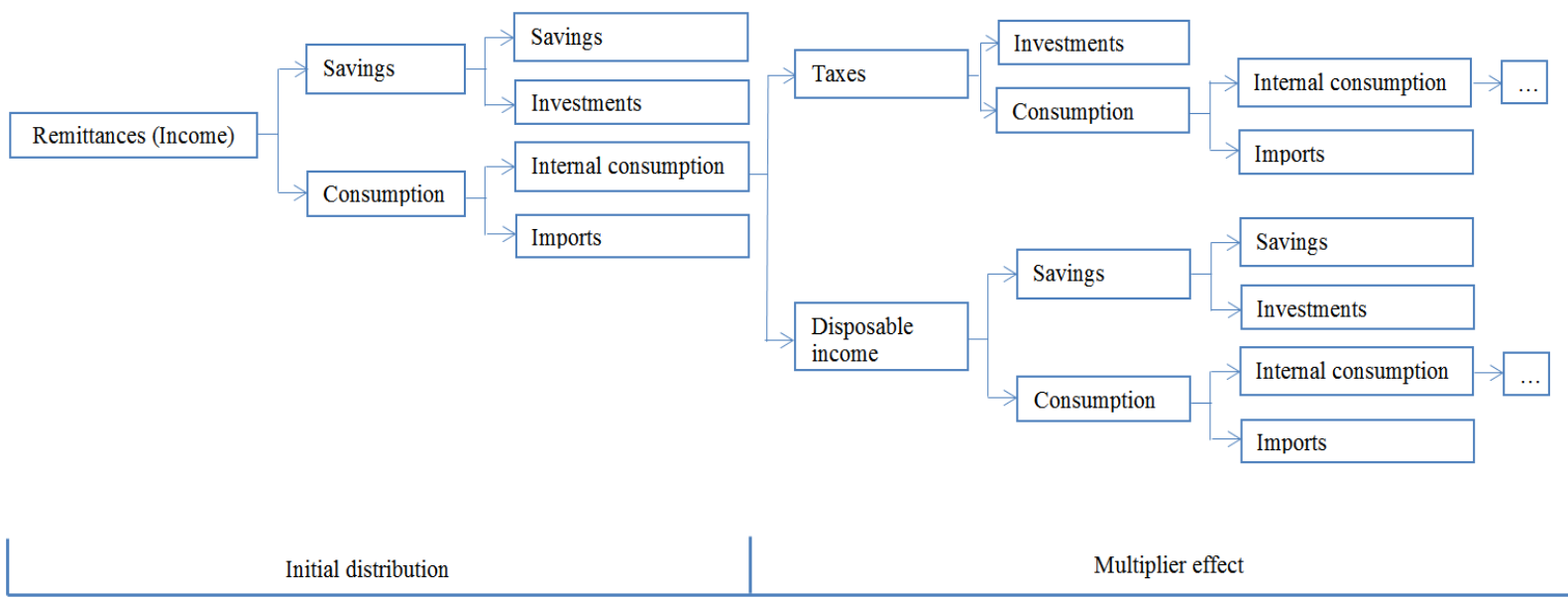

Figure 4. An extended model of remittances impact on receiving economy*

* developed by authors adapting The General Theory of Employment, Interest and Money (Keynes, 1936)

One more complication of the model could be made by adding a corporate sector. However, this along with providing a mathematical description of government role is the scope of following study. 


\section{Methodology}

Estimations in this study are made under the same assumptions from the previous section:

1. Received remittances are initially spent by households on savings and consumption.

2. All saving caused by remittances are spent by households on consumption or investments within a year.

3. All consumption is divided into internal consumption and import.

4. Internal consumption caused by the initial distribution of remittances from the other side is the disposable income of households and taxes of government.

5. Additional disposable income and taxes are then distributed due to the same marginal propensities to consume and import.

Using these assumptions and equations 1-5 we estimate the amounts of internal consumption $\left(\mathrm{C}_{\mathrm{I}}\right)$, imports (Imp), savings $(\mathrm{S})$ and $\mathrm{GDP}\left(\mathrm{GDP}_{\mathrm{R}}\right)$ caused by remittances effects. For a better understanding of the extent to which remittances influences the economy, we calculate the ratio of mentioned indicators to the country's GDP in a given year.

The influence on BoP is calculated with equation 6.

Data sets are obtained from World Bank Data. Marginal propensity to consume is calculated as ration of final consumption expenditures (World Bank Data, 2020a) to the sum of gross capital formation (World Bank Data, 2020b) and final consumption expenditures in a given year. Marginal propensity to import is calculated as a ratio of imports of goods and services (World Bank Data, 2020c) to GDP (World Bank Data, 2020e) plus imports of goods and services in a given year. The amounts of mentioned indicators including Personal remittances received (World Bank Data, 2020d) and GDP are in current prices of a given year.

\section{Limitations}

The amount of remittances received used for calculation accounts only registered remittances made usually through official channels. The actual amount of remittances received might occur to be higher (IOM, 2019). Therefore, the share of GDP caused by remittances effects might be underestimated.

Marginal propensities to consume and to import are calculated for all agents in an economy, so the calculated meanings are only a rough approximation of real situation. To obtain the accurate meanings of MPC and MPM additional researches are necessary. 
We assume that "all saving caused by remittances are spent by households on consumption or investments within a year". However, it is not clear if all savings were really spent, so the share of GDP caused by remittances effects on savings might be overestimated.

\section{Results}

Data in the first table 1 presents remittances' multiplier of GDP calculated for 2009-2019 period for top-30 countries in accordance to Remittances received to GDP ratio as of 2019 except Samoa due to the lack of data.

Table 1.

Remittances multiplier of GDP for chosen countries for 2009-2019 years*

\begin{tabular}{|c|c|c|c|c|c|c|c|c|c|c|c|}
\hline Country Name & 2009 & 2010 & 2011 & 2012 & 2013 & 2014 & 2015 & 2016 & 2017 & 2018 & 2019 \\
\hline 1 & 2 & 3 & 4 & 5 & 6 & 7 & 8 & 9 & 10 & 11 & 12 \\
\hline Haiti & 1,700 & 1,358 & 1,419 & 1,490 & 1,496 & 1,480 & 1,493 & 1,481 & 1,443 & 1,418 & 1,444 \\
\hline Tajikistan** & 1,401 & 1,463 & 1,361 & 1,355 & 1,430 & 1,697 & 1,729 & 1,688 & 1,746 & \#\#\# & \#\#\# \\
\hline Kyrgyz Republic & 1,165 & 1,141 & 1,144 & 1,031 & 1,056 & 1,083 & 1,183 & 1,235 & 1,277 & 1,256 & 1,284 \\
\hline Nepal & 1,799 & 1,667 & 1,732 & 1,778 & 1,660 & 1,556 & 1,572 & 1,686 & 1,483 & 1,383 & 1,362 \\
\hline Honduras & 1,470 & 1,360 & 1,245 & 1,260 & 1,300 & 1,333 & 1,356 & 1,440 & 1,403 & 1,372 & 1,467 \\
\hline El Salvador & 1,944 & 1,759 & 1,653 & 1,681 & 1,654 & 1,712 & 1,753 & 1,825 & 1,786 & 1,656 & 1,688 \\
\hline Lesotho & 0,923 & 0,959 & 0,997 & 0,960 & 1,049 & 1,098 & 1,099 & 1,088 & 1,073 & 1,046 & 1,062 \\
\hline Moldova & 1,243 & 1,418 & 1,331 & 1,343 & 1,357 & 1,371 & 1,453 & 1,501 & 1,508 & 1,463 & 1,463 \\
\hline Kosovo & 1,492 & 1,422 & 1,377 & 1,472 & 1,553 & 1,548 & 1,542 & 1,534 & 1,490 & 1,437 & 1,427 \\
\hline Jamaica & 1,556 & 1,627 & 1,542 & 1,590 & 1,557 & 1,528 & 1,680 & 1,707 & 1,598 & 1,542 & 1,542 \\
\hline Gambia & 2,750 & 2,701 & 2,733 & 2,233 & 2,562 & 2,258 & 2,378 & 2,313 & 1,972 & 1,901 & 1,801 \\
\hline Uzbekistan & 1,719 & 2,238 & 2,200 & 2,255 & 2,296 & 2,352 & 2,551 & 2,583 & 2,031 & 1,543 & 1,479 \\
\hline Guatemala & 2,306 & 2,138 & 2,057 & 2,116 & 2,151 & 2,231 & 2,391 & 2,565 & 2,580 & 2,499 & 2,510 \\
\hline Lebanon & 1,425 & 1,399 & 1,313 & 1,415 & 1,400 & 1,477 & 1,636 & 1,688 & 1,698 & 1,688 & 1,860 \\
\hline
\end{tabular}




\begin{tabular}{|c|c|c|c|c|c|c|c|c|c|c|c|}
\hline Nicaragua & 1,522 & 1,394 & 1,268 & 1,256 & 1,278 & 1,334 & 1,347 & 1,403 & 1,407 & 1,518 & 1,631 \\
\hline Georgia & 1,756 & 1,612 & 1,534 & 1,452 & 1,516 & 1,430 & 1,406 & 1,395 & 1,390 & 1,334 & 1,320 \\
\hline Cabo Verde & 1,306 & 1,244 & 1,222 & 1,304 & 1,396 & 1,298 & 1,351 & 1,308 & 1,226 & 1,211 & 1,249 \\
\hline Comoros** & 2,389 & 2,321 & 2,397 & 2,315 & 2,382 & 2,456 & 2,628 & 2,757 & 2,594 & 2,432 & \#\#\#\# \\
\hline $\begin{array}{l}\text { Bosnia and } \\
\text { Herzegovina }\end{array}$ & 1,676 & 1,657 & 1,533 & 1,531 & 1,571 & 1,513 & 1,577 & 1,582 & 1,474 & 1,470 & 1,491 \\
\hline Armenia & 1,556 & 1,540 & 1,566 & 1,595 & 1,636 & 1,675 & 1,784 & 1,805 & 1,626 & 1,517 & 1,585 \\
\hline Senegal & 2,132 & 2,148 & 1,987 & 1,795 & 1,831 & 1,829 & 1,853 & 1,939 & 1,765 & 1,695 & 1,672 \\
\hline Montenegro & 1,323 & 1,385 & 1,375 & 1,315 & 1,415 & 1,433 & 1,422 & 1,344 & 1,301 & 1,267 & 1,283 \\
\hline Ukraine & 1,669 & 1,550 & 1,444 & 1,457 & 1,575 & 1,641 & 1,535 & 1,456 & 1,486 & 1,538 & 1,742 \\
\hline Kiribati** & 1,108 & 1,225 & 1,124 & 1,074 & 1,045 & 0,981 & 0,955 & 0,938 & 0,973 & 1,087 & \#\#\# \\
\hline Jordan** & 1,268 & 1,261 & 1,227 & 1,233 & 1,274 & 1,302 & 1,437 & 1,523 & 1,508 & 1,548 & \#\#\# \\
\hline Liberia & 1,043 & 1,063 & 1,046 & 1,093 & 1,029 & 0,936 & 0,950 & 0,998 & 1,010 & 1,051 & 1,010 \\
\hline Guinea-Bissau & 2,320 & 2,335 & 2,549 & 3,196 & 3,126 & 2,478 & 2,565 & 2,640 & 2,471 & 2,424 & 2,373 \\
\hline Albania & 1,472 & 1,520 & 1,455 & 1,554 & 1,575 & 1,599 & 1,651 & 1,632 & 1,613 & 2,209 & 2,212 \\
\hline Philippines & 2,193 & 1,992 & 2,050 & 2,142 & 2,135 & 2,103 & 2,036 & 1,868 & 1,757 & 1,663 & 1,719 \\
\hline Egypt** & 2,131 & 2,326 & 2,531 & 2,645 & 2,808 & 2,917 & 2,953 & 3,055 & 2,431 & 2,350 & \#\#\# \\
\hline
\end{tabular}

* calculated using equation 5, data obtained from World Bank Data (2020a, 2020b, 2020c, 2020e)

** data for 2018/2019 or 2019 was not available for chosen countries

Values in this table present the ratio at which the amount of remittances received is converted into the amount of GDP. For all the analysed countries during the analysed period the multiplier value exceeded 0 , which means that remittances do not cause a negative impact on the receiving economy. Moreover, the multiplier values were higher than 1 and even 3 like in Guinea-Bissau in 2012-2013. It means that remittances when received are becoming a part of GDP through consumption and investments, and its actual impact might be even doubled or tripled by the multiplier effect. 
Having the ratio at which the remittances are converted into GDP, we calculated, using equitation 5, the share of the GDP caused specifically by remittances for all mentioned countries during the same period (see table 2).

Table 2.

The share of GDP caused by remittances effects for chosen countries for 2009-2019 years, \%*

\begin{tabular}{|c|c|c|c|c|c|c|c|c|c|c|c|}
\hline Country Name & 2009 & 2010 & 2011 & 2012 & 2013 & 2014 & 2015 & 2016 & 2017 & 2018 & 2019 \\
\hline 1 & 2 & 3 & 4 & 5 & 6 & 7 & 8 & 9 & 10 & 11 & 12 \\
\hline Haiti & 35,52 & 30,22 & 29,28 & 30,45 & 31,40 & 33,34 & 37,58 & 43,83 & 46,71 & 46,13 & 55,62 \\
\hline Tajikistan** & 44,06 & 52,40 & 56,79 & 57,19 & 62,60 & 63,00 & 49,71 & 45,34 & 54,58 & \#\#\# & \#\#\# \\
\hline Kyrgyz Republic & 24,40 & 30,13 & 31,55 & 31,70 & 32,78 & 32,52 & 29,91 & 36,16 & 41,20 & 40,83 & 36,60 \\
\hline Nepal & 41,76 & 36,08 & 38,62 & 45,20 & 48,09 & 45,81 & 49,41 & 52,63 & 40,80 & 39,31 & 36,68 \\
\hline Honduras & 24,96 & 22,47 & 19,76 & 19,86 & 21,77 & 22,74 & 23,70 & 25,62 & 26,22 & 27,27 & 31,57 \\
\hline El Salvador & 37,58 & 33,11 & 29,70 & 30,77 & 29,82 & 31,52 & 31,97 & 34,42 & 35,73 & 34,16 & 35,32 \\
\hline Lesotho & 28,53 & 25,78 & 24,69 & 21,08 & 20,05 & 17,26 & 17,18 & 22,78 & 24,53 & 22,09 & 21,37 \\
\hline Moldova & 30,92 & 35,65 & 28,68 & 30,63 & 31,32 & 29,92 & 28,90 & 27,29 & 25,54 & 23,46 & 23,36 \\
\hline Kosovo & 27,88 & 24,53 & 20,41 & 21,41 & 23,24 & 22,99 & 23,25 & 22,51 & 22,87 & 22,36 & 22,48 \\
\hline Jamaica & 24,37 & 24,94 & 22,48 & 23,28 & 23,72 & 24,95 & 27,96 & 29,51 & 26,58 & 24,54 & 24,11 \\
\hline Gambia & 15,13 & 20,25 & 17,71 & 16,79 & 20,45 & 25,30 & 23,87 & 32,63 & 30,03 & 23,83 & 28,13 \\
\hline Uzbekistan & 10,56 & 13,70 & 16,65 & 20,17 & 22,26 & 20,91 & 15,09 & 18,31 & 24,48 & 23,30 & 21,82 \\
\hline Guatemala & 24,46 & 21,85 & 19,57 & 20,85 & 21,53 & 22,18 & 24,92 & 28,59 & 30,24 & 32,25 & 34,87 \\
\hline Lebanon & 30,42 & 25,17 & 22,63 & 21,44 & 22,58 & 22,06 & 24,51 & 25,07 & 22,56 & 21,43 & 25,82 \\
\hline Nicaragua & 14,13 & 13,12 & 11,85 & 12,12 & 12,59 & 12,80 & 12,64 & 13,39 & 14,24 & 17,48 & 21,97 \\
\hline Georgia & 18,13 & 15,58 & 15,71 & 15,59 & 17,16 & 16,11 & 13,72 & 14,01 & 15,35 & 15,42 & 16,80 \\
\hline Cabo Verde & 10,35 & 9,79 & 11,59 & 13,25 & 13,27 & 13,74 & 17,00 & 16,62 & 15,00 & 14,38 & 14,87 \\
\hline
\end{tabular}




\begin{tabular}{|c|c|c|c|c|c|c|c|c|c|c|c|}
\hline Comoros* & 26,60 & 22,31 & 25,35 & 25,11 & 24,74 & 34,15 & 35,87 & 31,78 & 31,68 & 33,56 & \#\#\# \\
\hline $\begin{array}{l}\text { Bosnia and } \\
\text { Herzegovina }\end{array}$ & 20,24 & 17,58 & 16,10 & 16,41 & 16,92 & 17,18 & 17,52 & 17,27 & 16,44 & 16,48 & 16,81 \\
\hline Armenia & 25,91 & 27,76 & 27,77 & 28,76 & 32,24 & 29,98 & 25,22 & 23,66 & 21,70 & 18,12 & 17,72 \\
\hline Senegal & 17,79 & 19,57 & 17,93 & 15,88 & 17,17 & 17,85 & 18,33 & 20,17 & 18,06 & 17,70 & 17,89 \\
\hline Montenegro & 9,65 & 13,92 & 15,44 & 16,32 & 17,28 & 16,95 & 16,48 & 14,77 & 14,01 & 13,55 & 13,64 \\
\hline Ukraine & 8,47 & 7,44 & 6,92 & 7,00 & 8,30 & 9,04 & 14,29 & 14,77 & 16,07 & 17,26 & 17,89 \\
\hline Kiribati** & 11,75 & 12,28 & 10,53 & 9,96 & 9,74 & 8,94 & 7,84 & 8,58 & 9,33 & 11,04 & \#\#\# \\
\hline Jordan** & 18,19 & 17,04 & 15,46 & 15,12 & 19,99 & 22,82 & 20,20 & 17,00 & 16,41 & 16,40 & \#\#\# \\
\hline Liberia & 1,48 & 15,65 & 22,82 & 21,96 & 13,85 & 15,25 & 19,57 & 17,66 & 12,41 & 14,81 & 9,91 \\
\hline Guinea-Bissau & 13,71 & 12,62 & 12,09 & 14,74 & 19,07 & 21,74 & 20,79 & 12,64 & 19,25 & 21,26 & 23,19 \\
\hline Albania & 21,00 & 20,21 & 17,52 & 17,91 & 15,80 & 17,18 & 18,72 & 17,97 & 16,26 & 21,27 & 21,32 \\
\hline Philippines & 24,85 & 20,61 & 20,18 & 20,13 & 20,10 & 20,28 & 19,80 & 18,26 & 17,55 & 16,21 & 16,04 \\
\hline Egypt** $^{*}$ & 8,06 & 13,23 & 15,36 & 18,22 & 17,35 & 18,69 & 16,26 & 17,06 & 25,54 & 23,89 & \#\#\# \\
\hline
\end{tabular}

* calculated using equation 5, data obtained from World Bank Data (2020a, 2020b, 2020c, 2020d 2020e)

** data for 2018/2019 or 2019 was not available for chosen countries

For all analysed countries except Liberia, the share of GDP caused by the effects of received remittances was higher than $10 \%$ in 2019. For 26 out of 30 countries this indicator was higher than $15 \%$, for 11 countries higher than $25 \%$ and higher than 50 for Haiti and Tajikistan.

It once again emphasises the extremely high dependence of many countries on remittances. Such a condition of receiving countries might be compared with oil and gas exporting countries, which economies dramatically react to the change of its prices and demand. If one now imaging that a global pandemic which undermines the mobility, and economic crises in host countries may cut the remittances for $10 \%$, he or she can assume that receiving countries' economies will drop from 1\% up to even 5\% of GDP.

Table 3 presents the estimation of remittances impact on the components of GDP in observed countries as the share of these components in the GDP in 2019.

Table 3. 
The share of internal consumption, imports of goods and services, savings, and GDP caused by remittances effects in the current GDP for chosen countries in 2019, \%*

\begin{tabular}{|c|c|c|c|c|c|c|c|c|c|}
\hline $\begin{array}{l}\text { Country } \\
\text { Name }\end{array}$ & $\begin{array}{l}\text { Remit- } \\
\text { tances } \\
\% \text { of } \\
\text { GDP }\end{array}$ & $M_{C_{I^{\prime}}}^{R}$ & $\begin{array}{c}C_{I}, \\
\% \text { of } \\
\text { GDP }\end{array}$ & $M_{I m p}^{R}$, & $\begin{array}{l}\text { Imp, \% } \\
\text { of GDP }\end{array}$ & $M_{S}^{R}$ & $\mathbf{S}$ & $M_{G D P}^{R}$ & $\mathbf{G D P}_{R}$ \\
\hline 1 & 2 & 3 & 4 & 5 & 6 & 7 & 8 & 9 & 10 \\
\hline Haiti & 38,53 & 1,043 & 40,18 & 0,599 & 23,09 & 0,401 & 15,44 & 1,444 & 55,62 \\
\hline Tajikistan** & 31,25 & 1,263 & 39,49 & 0,517 & 16,16 & 0,483 & 15,10 & 1,746 & 54,58 \\
\hline $\begin{array}{l}\text { Kyrgyz } \\
\text { Republic }\end{array}$ & 28,51 & 0,827 & 23,58 & 0,543 & 15,49 & 0,457 & 13,02 & 1,284 & 36,60 \\
\hline Nepal & 26,92 & 0,674 & 18,15 & 0,312 & 8,39 & 0,688 & 18,53 & 1,362 & 36,68 \\
\hline Honduras & 21,52 & 1,069 & 23,02 & 0,603 & 12,97 & 0,397 & 8,55 & 1,467 & 31,57 \\
\hline El Salvador & 20,93 & 1,314 & 27,49 & 0,626 & 13,10 & 0,374 & 7,83 & 1,688 & 35,32 \\
\hline Lesotho & 20,13 & 0,688 & 13,85 & 0,626 & 12,60 & 0,374 & 7,53 & 1,062 & 21,37 \\
\hline Moldova & 15,97 & 1,034 & 16,51 & 0,571 & 9,12 & 0,429 & 6,85 & 1,463 & 23,36 \\
\hline Kosovo & 15,76 & 0,971 & 15,31 & 0,545 & 8,58 & 0,455 & 7,18 & 1,427 & 22,48 \\
\hline Jamaica & 15,64 & 1,107 & 17,31 & 0,565 & 8,84 & 0,435 & 6,80 & 1,542 & 24,11 \\
\hline Gambia & 15,62 & 1,435 & 22,41 & 0,633 & 9,89 & 0,367 & 5,73 & 1,801 & 28,13 \\
\hline Uzbekistan & 14,75 & 0,823 & 12,14 & 0,344 & 5,08 & 0,656 & 9,68 & 1,479 & 21,82 \\
\hline Guatemala & 13,89 & 2,103 & 29,21 & 0,592 & 8,23 & 0,408 & 5,66 & 2,510 & 34,87 \\
\hline Lebanon & 13,88 & 1,481 & 20,57 & 0,621 & 8,63 & 0,379 & 5,26 & 1,860 & 25,82 \\
\hline Nicaragua & 13,47 & 1,262 & 16,99 & 0,630 & 8,49 & 0,370 & 4,98 & 1,631 & 21,97 \\
\hline Georgia & 12,73 & 0,862 & 10,96 & 0,542 & 6,89 & 0,458 & 5,83 & 1,320 & 16,80 \\
\hline Cabo Verde & 11,90 & 0,719 & 8,56 & 0,470 & 5,59 & 0,530 & 6,31 & 1,249 & 14,87 \\
\hline Comoros** & 13,80 & 2,042 & 28,17 & 0,609 & 8,41 & 0,391 & 5,39 & 2,432 & 33,56 \\
\hline $\begin{array}{l}\text { Bosnia and } \\
\text { Herzegovina }\end{array}$ & 11,28 & 1,108 & 12,50 & 0,618 & 6,97 & 0,382 & 4,31 & 1,491 & 16,81 \\
\hline Armenia & 11,18 & 1,243 & 13,89 & 0,658 & 7,35 & 0,342 & 3,82 & 1,585 & 17,72 \\
\hline
\end{tabular}




\begin{tabular}{|c|c|c|c|c|c|c|c|c|c|} 
Senegal & 10,70 & 1,079 & 11,54 & 0,407 & 4,35 & 0,593 & 6,34 & 1,672 & 17,89 \\
\hline Montenegro & 10,63 & 0,817 & 8,68 & 0,534 & 5,68 & 0,466 & 4,96 & 1,283 & 13,64 \\
\hline Ukraine & 10,27 & 1,455 & 14,94 & 0,713 & 7,32 & 0,287 & 2,94 & 1,742 & 17,89 \\
\hline Kiribati** & 10,15 & 0,779 & 7,91 & 0,691 & 7,02 & 0,309 & 3,14 & 1,087 & 11,04 \\
\hline Jordan** & 10,59 & 1,207 & 12,78 & 0,658 & 6,97 & 0,342 & 3,62 & 1,548 & 16,40 \\
\hline Liberia & 9,81 & 0,772 & 7,57 & 0,762 & 7,48 & 0,238 & 2,33 & 1,010 & 9,91 \\
\hline Guinea-Bissau & 9,77 & 2,066 & 20,19 & 0,692 & 6,76 & 0,308 & 3,01 & 2,373 & 23,19 \\
\hline Albania & 9,64 & 2,212 & 21,32 & 1,000 & 9,64 & 0,000 & 0,00 & 2,212 & 21,32 \\
\hline Philippines & 9,33 & 1,203 & 11,23 & 0,484 & 4,52 & 0,516 & 4,81 & 1,719 & 16,04 \\
\hline Egypt** & 10,17 & 1,911 & 19,43 & 0,561 & 5,71 & 0,439 & 4,46 & 2,350 & 23,89 \\
\hline
\end{tabular}

* calculated using equation 1, 2, 3, 4, 5, data obtained from World Bank Data (2020a, 2020b, 2020c, 2020d 2020e)

** due to the lack of data, indicators for Tajikistan are presented as of 2017, for Comoros, Kiribati, Jordan and Egypt are presented as of 2018.

As the presented estimation is provided for GDP components its result directly corresponds with the conclusion for table 2. However, the share of savings indicates how future development and countries' stability depends on remittances. Moreover, when the amount of imports is excluded from the GDP, the imported goods and services still remain in the receiving countries improving the welfare of households.

The final table 4 presents a calculation of net money flows caused by remittances.

Table 4.

Net money flows caused by remittances effects for chosen countries during 2009-2019, \$US bn.*

\begin{tabular}{|c|c|c|c|c|c|c|c|c|c|c|c|}
\hline Country Name & $\mathbf{2 0 0 9}$ & $\mathbf{2 0 1 0}$ & $\mathbf{2 0 1 1}$ & $\mathbf{2 0 1 2}$ & $\mathbf{2 0 1 3}$ & $\mathbf{2 0 1 4}$ & $\mathbf{2 0 1 5}$ & $\mathbf{2 0 1 6}$ & $\mathbf{2 0 1 7}$ & $\mathbf{2 0 1 8}$ & $\mathbf{2 0 1 9}$ \\
\hline 1 & 2 & 3 & 4 & 5 & 6 & 7 & 8 & 9 & 10 & 11 & 12 \\
\hline Haiti & 0,662 & 0,505 & 0,617 & 0,716 & 0,820 & 0,918 & 1,089 & 1,099 & 1,156 & 1,293 & 1,312 \\
\hline \begin{tabular}{c} 
Tajikistan** \\
\hline $\begin{array}{c}\text { Kyrgyz } \\
\text { Republic }\end{array}$
\end{tabular} & 0,562 & 0,698 & 1,027 & 1,013 & 1,245 & 1,421 & 1,055 & 0,935 & 1,081 & $\# \# \#$ & $\# \#$ \\
\hline
\end{tabular}




\begin{tabular}{|c|c|c|c|c|c|c|c|c|c|c|c|}
\hline Nepal & 1,719 & 2,142 & 2,701 & 2,907 & 3,378 & 3,636 & 4,002 & 3,676 & 4,469 & 5,572 & 5,677 \\
\hline Honduras & 0,910 & 0,967 & 1,126 & 1,126 & 1,091 & 1,246 & 1,527 & 1,600 & 1,842 & 2,024 & 2,146 \\
\hline El Salvador & 1,065 & 1,172 & 1,236 & 1,345 & 1,298 & 1,366 & 1,411 & 1,560 & 1,747 & 2,075 & 2,117 \\
\hline Lesotho & 0,034 & 0,043 & 0,045 & 0,051 & 0,057 & 0,055 & 0,049 & 0,043 & 0,044 & 0,052 & 0,055 \\
\hline Moldova & 0,439 & 0,648 & 0,645 & 0,712 & 0,824 & 0,822 & 0,598 & 0,556 & 0,640 & 0,767 & 0,819 \\
\hline Kosovo & 0,494 & 0,477 & 0,476 & 0,424 & 0,480 & 0,467 & 0,436 & 0,440 & 0,509 & 0,560 & 0,569 \\
\hline Jamaica & 0,732 & 0,777 & 0,794 & 0,790 & 0,824 & 0,891 & 0,982 & 1,045 & 1,054 & 1,087 & 1,119 \\
\hline Gambia & 0,031 & 0,045 & 0,036 & 0,056 & 0,047 & 0,053 & 0,045 & 0,081 & 0,086 & 0,073 & 0,101 \\
\hline Uzbekistan & 1,304 & 1,987 & 2,987 & 3,894 & 4,491 & 4,762 & 3,506 & 4,192 & 4,825 & 5,014 & 5,605 \\
\hline Guatemala & 1,413 & 1,485 & 1,675 & 1,833 & 2,060 & 2,211 & 2,606 & 2,965 & 3,334 & 3,678 & 4,344 \\
\hline Lebanon & 3,269 & 2,758 & 2,734 & 2,564 & 3,123 & 2,826 & 2,965 & 3,158 & 2,791 & 2,644 & 2,805 \\
\hline Nicaragua & 0,317 & 0,340 & 0,420 & 0,470 & 0,503 & 0,528 & 0,621 & 0,646 & 0,699 & 0,679 & 0,623 \\
\hline Georgia & 0,315 & 0,461 & 0,620 & 0,776 & 0,772 & 0,862 & 0,644 & 0,755 & 0,846 & 0,962 & 1,035 \\
\hline Cabo Verde & 0,081 & 0,079 & 0,106 & 0,097 & 0,091 & 0,106 & 0,099 & 0,114 & 0,115 & 0,129 & 0,125 \\
\hline Comoros & 0,045 & 0,038 & 0,043 & 0,042 & 0,047 & 0,062 & 0,050 & 0,043 & 0,049 & 0,064 & 0,000 \\
\hline $\begin{array}{l}\text { Bosnia and } \\
\text { Herzegovina }\end{array}$ & 0,760 & 0,563 & 0,642 & 0,608 & 0,635 & 0,696 & 0,614 & 0,668 & 0,748 & 0,848 & 0,865 \\
\hline Armenia & 0,845 & 0,935 & 0,900 & 0,846 & 0,896 & 0,833 & 0,649 & 0,551 & 0,595 & 0,608 & 0,523 \\
\hline Senegal & 0,618 & 0,677 & 0,723 & 0,775 & 0,870 & 1,005 & 0,935 & 1,083 & 1,233 & 1,416 & 1,496 \\
\hline Montenegro & 0,120 & 0,146 & 0,166 & 0,167 & 0,185 & 0,191 & 0,165 & 0,198 & 0,237 & 0,274 & 0,272 \\
\hline Ukraine & 2,561 & 2,784 & 3,324 & 3,458 & 3,603 & 2,226 & 2,887 & 3,928 & 4,714 & 5,445 & 4,528 \\
\hline Kiribati** & 0,003 & 0,003 & 0,003 & 0,005 & 0,005 & 0,004 & 0,005 & 0,005 & 0,005 & 0,006 & \#\#\# \\
\hline Jordan** & 1,478 & 1,609 & 1,443 & 1,396 & 1,761 & 2,137 & 1,895 & 1,531 & 1,527 & 1,528 & \#\#\# \\
\hline Liberia & 0,005 & 0,061 & 0,108 & 0,127 & 0,090 & 0,097 & 0,124 & 0,117 & 0,085 & 0,067 & 0,072 \\
\hline Guinea-Bissau & 0,014 & 0,013 & 0,016 & 0,011 & 0,017 & 0,030 & 0,022 & 0,014 & 0,029 & 0,040 & 0,040 \\
\hline
\end{tabular}




\begin{tabular}{|c|c|c|c|c|c|c|c|c|c|c|c|} 
Albania & 0,911 & 0,808 & 0,787 & 0,706 & 0,629 & 0,660 & 0,616 & 0,608 & 0,609 & 0,000 & 0,000 \\
\hline Philippines & 9,425 & $\begin{array}{c}10,91 \\
5\end{array}$ & $\begin{array}{c}11,82 \\
5\end{array}$ & $\begin{array}{c}12,35 \\
0\end{array}$ & $\begin{array}{c}13,93 \\
3\end{array}$ & $\begin{array}{c}15,05 \\
9\end{array}$ & $\begin{array}{c}15,31 \\
5\end{array}$ & $\begin{array}{c}16,52 \\
5\end{array}$ & $\begin{array}{c}17,17 \\
6\end{array}$ & $\begin{array}{c}17,60 \\
3\end{array}$ & $\begin{array}{c}18,12 \\
9\end{array}$ \\
\hline Egypt** & 3,414 & 6,475 & 7,136 & 9,068 & 8,007 & 8,568 & 8,431 & 9,099 & $\begin{array}{c}10,06 \\
6\end{array}$ & $\begin{array}{c}11,19 \\
9\end{array}$ & $\# \# \#$ \\
\hline
\end{tabular}

* calculated using equation 6, data is obtained from World Bank Data (2020a, 2020b, 2020c, 2020d 2020e)

** data for 2018/2019 or 2019 was not available for chosen countries

Estimation of the net money flows indicates that remittances caused a net money inflow for all chosen countries during the analysed period. Other words, in all chosen countries in any of analysed year the money inflow caused by remittances exceeded money outflows caused by imports even if the multiplier effect was considered.

Such results undermine the conclusions of the possible negative impact of remittances on the trade balance. However, under particular circumstances, it might become a cause of "Dutch disease".

\section{Conclusions}

Numerous discussions about the impact of personal remittances on the economic development of countries receiving them provide controversial evidences. Instead of applying commonly used methods of regression analysis, the current study provides a method based on Keynesian economics.

Assuming that remittances are initially distributed for consumption and savings, which then is distributed for internal consumption and import, we developed equations for estimating the remittances multipliers of GDP, internal consumption, imports and savings. Multiplying the amount of remittances with respective multiplier provides the estimation of the share of GDP, internal consumption, imports and savings caused by remittances' effects in the total amount of GDP.

Having the estimated amount of imports, including its multiplied amount, we calculated the net money flow caused by remittances effects as the difference between remittances received and imports.

Estimation of TOP-30 countries in remittances received to GDP ranking indicates that only one out of 30 countries had less than $10 \%$ of GDP caused by remittances. For 26 out of 30 countries this indicator was higher than $15 \%$, for 11 countries it was higher than $25 \%$. Estimation of net money flows indicates that in all countries during the analysed period the 
amount of outflow caused by increased import did not exceed the amount of received remittances.

Presented results provide evidence of the positive impact of remittances on receiving countries. However, it once again stresses the high dependence of such countries on remittances. The drop of $10 \%$ in the amount of remittances may cause from $1 \%$ to $5 \%$ decrease in GDP. The estimation of net money flows caused by remittances undermines the conclusions about the negative impact of remittances on trade deficit; however, does not refute the assumption about "Dutch disease".

Further, we plan to improve presented equations by including the government. More accurate data on marginal propensity to consume and imports is also under the search. Findings, presented in this and previous (Malibroda, et al., 2020; Chernobay, Adamyk, \& Malibroda, 2019) studies, are planned to be combined into a single model to fully describe the impact of migration on economic development of a country.

\section{References}

1. Catrinescu, Natalia et al., 2009. Remittances, Institutions, and Economic Growth. World development, 37(1), pp. 81-92. https://doi.org/10.1016/j.worlddev.2008.02.004

2. Cazachevici, Alina, Havranek, Tomas \& Horvath, Roman, 2020. Remittances and economic growth: A meta-analysis. World development, 134, p. 105021. https://doi.org/ $\underline{10.1016 / j . w o r l d d e v .2020 .105021}$

3. Chami, R., Fullenkamp, C. \& Jahjah, S., 2003. Are Immigrant Remittance Flows a Source of Capital for Development, [Place of publication not identified]: International Monetary Fund. https://doi.org/10.2139/ssrn.463002

4. Chernobay, L., Adamyk, V., \& Malibroda, S. (2019). An approach to modelling the impact of international migration on the economy of receiving country. Economics, Entrepreneurship, Management, 6(1), 47-69. https://doi.org/10.23939/eem2019.01.047

5. Farzanegan, Mohammad Reza \& Hassan, Sherif Maher, 2019. How does the flow of remittances affect the trade balance of the Middle East and North Africa? Journal of economic policy reform, pp. 1-19.

6. Feeny, Simon, Iamsiraroj, Sasi \& McGillivray, Mark, 2014. Remittances and Economic Growth: Larger Impacts in Smaller Countries? The Journal of development studies, 50(8), pp.1055-1066. https://doi.org/10.1080/00220388.2014.895815

7. Gapen, M.T. et al., 2009. Do Workers' Remittances Promote Economic Growth?, Washington: International Monetary Fund. https://doi.org/10.5089/9781451873009.001 
8. Hassan, Gazi M \& Holmes, Mark J, 2016. Do Remittances Facilitate a Sustainable Current Account? World economy, 39(11), pp.1834-1853. https://doi.org/10.1111/ $\underline{\text { twec. } 12361}$

9. Imai, Katsushi S., Raghav Gaiha, Abdilahi Ali, and Nidhi Kaicker (2014) Remittances, Growth and Poverty: New Evidence from Asian Countries. Journal of Policy Modeling 36: 524-538. https://doi.org/10.1016/j.jpolmod.2014.01.009

10. IOM, 2019. World Migration Report 2020, UN, New York. https://doi.org/10.18356/b1710e30-en

11. Keynes, J.M., 1936. The general theory of employment, interest and money

12. Lucas, R.E.B., 1987. Emigration to South Africa's Mines. The American economic review., 77, pp. 313-30.

13. Marwan, Nur F., Kadir, Nur A. A., Hussin, Adibah, Zaini, Azniza, Rashid, M. E., and Helmi, Z.A.G. (2013) Export, Aid, Remittance and Growth: Evidence from Sudan. Procedía Economics and Finance 7:3-10. https://doi.org/10.1016/S2212-5671(13)00211-6

14. Mundaca, B.G., 2009. Remittances, Financial Market Development, and Economic Growth: The Case of Latin America and the Caribbean. Review of development economics, 13(2), pp.288-303. https://doi.org/10.1111/j.1467-9361.2008.00487.x

15. Oladipo, O.S., 2020. Migrant Workers' Remittances And Economic Growth: A Time Series Analysis. The Journal of developing areas, 54(4), pp. 75-88. https:// doi.org/10.1353/jda.2020.0038

16. Peprah, James Atta, Kwesi Ofori, Isaac \& Asomani, Abel Nyarko, 2019. Financial development, remittances and economic growth: A threshold analysis. Cogent economics \& finance, 7(1), p. 1625107. https://doi.org/10.1080/23322039.2019.1625107

17. Pradhan, Gyan, Upadhyay, Mukti \& Upadhyaya, Kamal, 2008. Remittances and economic growth in developing countries. European journal of development research, 20(3), pp. 497-506. https://doi.org/10.1080/09578810802246285

18. Richard H. Adams JR (2011) Evaluating the Economic Impact of International Remittances On Developing Countries Using Household Surveys: A Literature Review, The Journal of Development Studies, 47:6, 809-828. https://doi.org/10.1080/ $\underline{00220388.2011 .563299}$

19. Rozelle, S., Taylor, J.E. \& DeBrauw, A., 1999. Migration, Remittances, and Agriculture Productivity in China. The American economic review., 89, pp. 287-91. https://doi.org/10.1257/aer.89.2.287 
20. Saad-Filho, Alfredo \& Weeks, John, 2013. Curses, Diseases and Other Resource Confusions. Third world quarterly, 34(1), pp. 1-21. https://doi.org/10.1080/ $\underline{01436597.2012 .755010}$

21. Salahuddin, Mohammad (2013) Empirical Link between Growth and Remittance: Evidence from Panel Data. Journal of Applied Business and Economics 14: 19-29.

22. Shahbaz, Muhammad, Rehman, Ijaz Ur \& Mahdzan, Nurul Shahnaz Ahmad, 2013. Linkages between income inequality, international remittances and economic growth in Pakistan. Quality \& quantity, 48(3), pp. 1511-1535. https://doi.org/10.1007/s11135-013$\underline{9850-4}$

23. Singh, R. J et al., 2010. Determinants and Macroeconomic Impact of Remittances in Sub-Saharan Africa. Journal of African economies, 20(2), pp. 312-340. https://doi.org/10.1093/jae/ejq039

24. Stahl, C.W \& Arnold, F, 1986. Overseas workers' remittances in Asian development ( migrants). The International migration review, 20(4), pp. 899-925. https://doi.org/10.1177/019791838602000409

25. Malibroda Sviatoslav et al., 2020. Modelling the Impact of International Migration on Economic Development of a Country: Case Study of Ukraine. Ekonomický časopis, 68(1), pp. 33-54.

26. Tung, L.T., 2018. Impact of remittance inflows on trade balance in developing countries. Economics \& sociology, 11(4), pp.80-95. https://doi.org/10.14254/2071$\underline{789 X .2018 / 11-4 / 5}$

27. Woodruff, C. \& Zenteno, R., 2007. Migration Networks and Microenterprises in Mexico. Journal of development economics., 82, pp. 509-28. https://doi.org/10.1016/ j.jdeveco.2006.03.006

28. World Bank, 2020a. Final Consumption Expenditure (Current US\$). [online] Data.worldbank.org. Available at: https://data.worldbank.org/indicator/NE.CON.TOTL.CD [Accessed 25 November 2020].

29. World Bank, 2020b. Gross Capital Formation (Current US\$). [online] Data.worldbank.org. Available at: https://data.worldbank.org/indicator/NE.GDI.TOTL.CD [Accessed 25 November 2020].

30. World Bank. 2020c. Imports Of Goods And Services (Current US\$). [online] Available at: https://data.worldbank.org/indicator/NE.IMP.GNFS.CD [Accessed 25 November 2020]. 
31. World Bank. 2020d. Personal Remittances, Received (Current US\$). [online] Available at: https://data.worldbank.org/indicator/BX.TRF.PWKR.CD.DT [Accessed 25 November 2020].

32. World Bank. 2020e. GDP (Current US\$). [online] Available at: https://data.worldbank.org/indicator/NY.GDP.MKTP.CD [Accessed 25 November 2020]. 